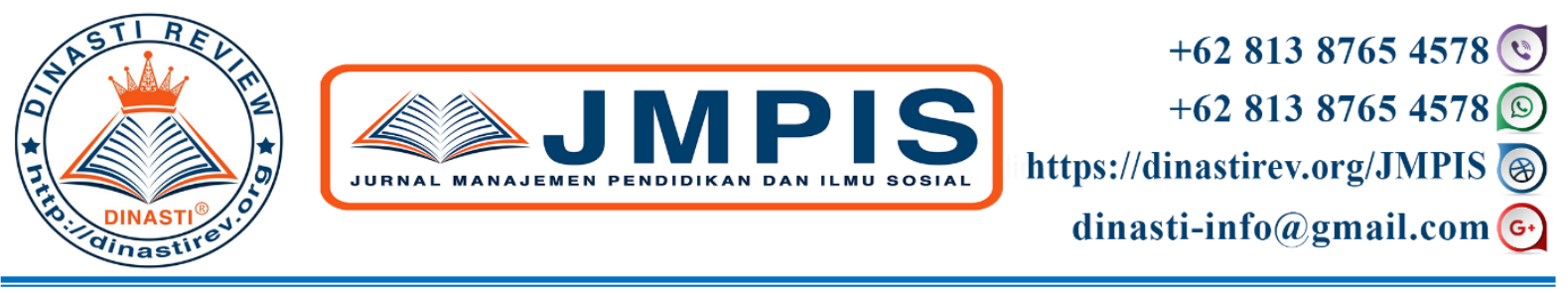

\title{
PENGARUH KREATIVITAS, EFIKASI DIRI, DAN MOTIVASI TERHADAP KESIAPAN BERWIRAUSAHA MAHASISWA FAKULTAS KEGURUAN DAN ILMU PENDIDIKAN UNIVERSITAS JAMBI
}

\section{Delma yunita}

Universitas Jambi, Kota Jambi, Indonesia

\begin{tabular}{c}
\hline ARTICLE INFORMATION \\
Received: 25 Juni 2020 \\
Revised: 8 Juli 2020 \\
Issued: 12 Juli 2020 \\
Corresponding author: first \\
author \\
E-mail: \\
Deeelmaaaaa@ gmail.com
\end{tabular}

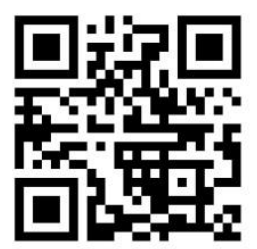

DOI:10.38035/JMPIS
Abstrak.: Rendahnya jumlah wirausaha dan meningkatnya angka pengangguran terdidik di Indonesia terutama pada lulusan universitas menunjukkan bahwa berbagai program pembelajaran kewirausahaan di universitas yang sudah dikembangkan selama dua dekade belum berhasil meningkatkan semangat dan jiwa kewirausahaan mahasiswa sehingga keinginan berwirausaha mahasiswa relatif rendah. Tujuan penelitian : untuk mendeskripsikan kesiapan, kreativitas, efikasi diri dan motivasi berwirausaha mahasiswa Fakultas Keguruan dan Ilmu Pendidikan Universitas Jambi, untuk menganalisis pengaruh kreativitas terhadap kesiapan berwirausaha, Untuk menganalisis pengaruh efikasi diri terhadap kesiapan berwirausaha. Untuk menganalisis pengaruh motivasi terhadap kesiapan kewirausahaan, Untuk menganalisis pengaruh kreativitas, efikasi diri, dan motivasi secara bersama-sama terhadap kesiapan kewirausahaan. Berdasarkan tujuan penelitian, penelitian ini adalah Penelitian yang dilakukan melalui survey dengan menyebarkan angket kepada mahasiswa Fakultas Keguruan dan Ilmu Pendidikan Unversitas Jambi, dengan menggunakan pendekatan kuantitatif.. Hasil analisis data variabel motivasi berwirausaha sebesar 11,428, dengan nilai signifikansi sebesar 0,000, dikarenakan angka taraf signifikansi $<0,05(0,000<0,05)$ maka dapat disimpulkan bahwa motivasi berwirausaha berpengaruh terhadap kesiapan berwirausaha mahasiswa., Hasil ini diperoleh angka $t$ hitung variabel motivasi berwirausaha sebesar 21,325, dengan nilai signifikansi sebesar 0,000, dikarenakan angka taraf signifikansi < $0,05(0,000<0,05)$ maka dapat disimpulkan bahwa motivasi berwirausaha berpengaruh terhadap kesiapan berwirausaha mahasiswa, melalui hasil uji Anova atau F test dengan menggunakan SPSS 21.0 didapat Fhitung sebesar 176,371 dengan tingkat probabilitas p-value sebesar 0,000, dikarenakan angka taraf signifikansi jauh lebih $<0,05(0,000<0,05)$ maka dapat disimpulkan bahwa kreativitas, efikasi diri dan motivasi berwirausaha secara bersama-sama (simultan) berpengaruh secara signifikan terhadap kesiapan berwirausaha mahasiswa FKIP Universitas Jambi.

Kata Kunci: Pengaruh Kreativitas, Efikasi Diri, Motivasi, Kesiapan Berwirausaha

\section{PENDAHULUAN}

Rendahnya jumlah wirausaha dan meningkatnya angka pengangguran terdidik di Indonesia terutama pada lulusan universitas menunjukkan bahwa berbagai program pembelajaran kewirausahaan di universitas yang sudah dikembangkan selama dua dekade belum berhasil meningkatkan semangat dan jiwa kewirausahaan mahasiswa sehingga keinginan berwirausaha mahasiswa relatif rendah. Oleh karena itu sampai saat ini 
pemerintah terus mendorong berbagai universitas di Indonesia untuk berlomba-lomba mencari skema pembelajaran kewirausahaan yang paling baik yang tidak hanya memberikan keterampilan berwirausaha, tetapi juga dapat meningkatkan semangat dan jiwa kewirausahaan mahasiswa serta dapat mengubah pola pikir mahasiswa yang masih berorientasi sebagai job seeker menjadi job creator

Kesiapan berwirausaha merupakan kemampuan dan kemauan peserta didik untuk menyiapkan segala sesuatu yang diperlukan ketika ingin memulai berwirausaha. Untuk dapat memiliki kemampuan tersebut maka diperlukan berbagai kemampuan di bidang wirausaha sehingga siap berwirausaha.

Banyak faktor yang dapat mempengaruhi kesiapan berwirausaha mahasiswa, dimana secara garis besar faktor-faktor tersebut yaitu faktor yang berasal dari diri siswa (intern) dan faktor yang berasal dari luar diri siswa (ekstern). Faktor-faktor yang berasal dari dalam diri siswa yaitu kematangan baik fisik maupun mental, ketekunan, kreativitas, minat, bakat, intelengensi, efikasi diri, pengetahuan dan motivasi.

Kewirausahaan pada dasarnya adalah sifat, ciri dan watak seseorang yang memiliki kemauan dalam mewujudkan gagasan inovatif ke dalam dunia nyata secara kreatif. Kewirausahaan (entrepreneurship) selalu mencari hal-hal yang baru sebagai tantangan untuk berubah dan dengan perubahan tersebut dimanfaatkan sebagai peluang.

Selain kreatifitas, adapun faktor lainnya yang memiliki pengaruh terhadap kesiapan berwirausaha adalah efikasi diri. Hal ini dikemukakan oleh Sari, A.K (2013:1) dimana hasil penelitiannya mengungkapkan bahwa efikasi diri berpengaruh terhadap kesiapan berwirausaha. Selain itu Bandura dalam Puspitaningsih, F (2014: 226) yang mengemukakan bahwa efikasi diri mempengaruhi bentuk tindakan yang akan mereka pilih untuk dilakukan, sebanyak apa usaha yang akan mereka berikan ke dalam aktivitas ini, selama apa mereka akan bertahan menghadapi rintangan dan kegagalan, serta ketangguhan mereka mengikuti adanya kemunduran". Keyakinan dan kemampuan diri mahasiswa inilah yang berkaitan dengan motivasinya.

Selain kreativitas dan efikasi diri, adapun faktor yang lain yang berpengaruh tehadap kesiapan berwirausaha adalah motivasi berwirausaha. Hal ini dikemukakan oleh Nastiti, N.D (2019:61) yang mengungkapkan bahwa motivasi kewirausahaan merupakan faktor yang paling mempengaruhi mahasiswa terhadap kesiapan berwirausaha.

Tujuan Penelitian dalam penelitian ini untuk mendeskripsikan kesiapan, kreativitas, efikasi diri dan motivasi berwirausaha mahasiswa Fakultas Keguruan dan Ilmu Pendidikan Universitas Jambi, untuk menganalisis pengaruh kreativitas terhadap kesiapan berwirausaha, Untuk menganalisis pengaruh efikasi diri terhadap kesiapan berwirausaha. Untuk menganalisis pengaruh motivasi terhadap kesiapan kewirausahaan, Untuk menganalisis pengaruh kreativitas, efikasi diri, dan motivasi secara bersama-sama terhadap kesiapan kewirausahaan. Definisi Konseptual dalam penelitian ini adalah Kesiapan wirausaha, Kesiapan wirausaha adalah keseluruhan kondisi seseorang yang membuatnya mampu untuk memberi respon atau jawaban dalam kegiatan berwirausaha, Kreativitas wirausaha, Kreativitas wirausaha adalah kemampuan mahasiswa untuk mengembangkan ide-ide baru dan cara baru dalam pemecahan masalah, menemukan peluang, atau membuat sesuatu yang baru sehingga bermanfaat dan dapat memenuhi kebutuhan hidup bagi dirinya dan orang lain, Efikasi diri, Efikasi diri merupakan rasa percaya diri yang dimiliki seseorang bahwa dirinya mampu untuk menyelesaikan tugas dengan efektif dan efisien sehingga tugas tersebut menghasilkan dampak yang diharapkan. Efikasi diri yang merujuk pada keyakinan diri sendiri mampu melakukan sesuatu yang diinginkannya, dapat dijadikan prediksi tingkah laku, Motivasi, Motivasi merupakan dorongan psikologis dari dalam maupun luar diri seseorang untuk bisa melakukan wirausaha. Dengan adanya dorongan tersebut, seseorang dapat menentukan usaha apa yang akan dikelolanya sekaligus juga dapat menentukan nasibnya 
dimasa depan. Defenisi Operasional dalam penelitian ini adalah 1) Kesiapan Berwirausaha 2) Kreativitas 3) Efikasi Diri 4) Motivasi

\section{KAJIAN PUSTAKA}

\section{Kesiapan Berwirausaha}

Kesiapan adalah tingkat perkembangan dari kematangan atau kedewasaan yang menguntungkan untuk dipraktikkan sesuatu. Pengertian ini mengacu pada pengetahuan, keterampilan serta sikap yang dimiliki seseorang berkaitan dengan tujuan yang akan dicapai. Kesiapan atau readiness merupakan kesediaan untuk memberikan respon atau bereaksi. Kesediaan itu datang dari dalam diri siswa dan juga berhubungan dengan kematangan. Kesiapan sangat perlu diperhatikan dalam suatu proses, karena jika siswa sudah ada kesiapan, maka hasilnya akan memuaskan (Chaplin, 2010:418).

Slameto (2015:113) mendefinisikan kesiapan adalah keseluruhan kondisi yang membuatnya siap untuk memberi respon/jawaban di dalam cara tertentu terhadap suatu kecenderungan untuk memberi respon. Kondisi mencakup setidaktidaknya tiga aspek yaitu: (1) kondisi fisik, mental dan emosional, (2) kebutuhan-kebutuhan, motif dan tujuan, (3) keterampilan, pengetahuan dan pengertian lain yang telah dipelajari. Kesiapan (readiness) seseorang merupakan sifat-sifat dan kekuatan pribadi yang berkembang dan memungkinkan orang untuk dapat menyesuaikan diri dengan lingkungannya serta mampu memecahkan persoalan yang dihadapinya. Sementara kematangan (maturity) membentuk sifat dan kekuatan dalam diri untuk bereaksi dengan cara tertentu (Soemanto, 2013:192-197). Kaitannya dengan mahasiswa, kematangan yang dimiliki selanjutnya akan menumbuhkan kapasitas mental sekaligus mempengaruhi aktivitas belajar dan tingkat kesiapan mereka bekerja. Hal senada yang dikatakan oleh Dalyono (2011:166) readiness seseorang itu merupakan sifat-sifat dan kekuatan pribadi yang berkembang. Perkembangan ini memungkinkan orang itu untuk dapat menyesuaikan diri dengan lingkungannya serta mampu memecahkan persoalan yang selalu dihadapinya.

Kesiapan wirausaha adalah keseluruhan kondisi seseorang yang membuatnya mampu untuk memberi respon atau jawaban dalam kegiatan berwirausaha. Dengan indikator yaitu: 1) Kemampuan Mental; 2) Berorientasi kemasa depan: pandangan dan keinginan yang kuat; 3) Kemampuan mengambil resiko: mempelajari cara mengenal risiko dan mengatasi risiko; dan 4) Keterampilan berwirausaha: membangun jaringan dan kemampuan mempengaruhi orang lain.

\section{Kreativitas Berwirausaha}

Kreativitas wirausaha menurut Alma (2018:69) adalah kemampuan untuk membuat kombinasi-kombinasi baru atau meliht hubungan-hubungan baru antara unsur variabel data variabel yang sudah ada sebelumnya. Adapun Supriadi (dalam Alma, 2018:70), kreativitas wirausaha merupakan kemampuan seorang untuk melahirkan sesuatu yang baru,baik berupa gagasan maupun karya nyata yang relatif berbeda dengan apa yang telah ada sebelumnya.

Pengukuran-pengukuran kreativitas dapat dibedakan atas pendekatan pendekatan yang digunakan untuk mengukurnya. Ada lima pendekatan yang lazim digunakan untuk mengukur kreativitas, yaitu: Analisis obyektif terhadap perilaku kreatif, Pertimbangan subyektif, Inventori kepribadian, Inventori biografis, Tes kreativitas.

Kreativitas wirausaha adalah kemampuan mahasiswa untuk mengembangkan ide-ide baru dan cara baru dalam pemecahan masalah, menemukan peluang, atau membuat sesuatu yang baru sehingga bermanfaat dan dapat memenuhi kebutuhan hidup bagi dirinya dan orang lain. Dengan indikator yaitu: 1) ingin tahu, meliputi: ingin tahu apa yang sedang laku dipasaran dan ingin tahu bagaimana gambaran di luar tentang produksi usaha; 2) optimis, 
meliputi: yakin dalam melakukan usaha yang sedang di jalankan, dan mempunyai keyakinan jika produknya akan laku dipasaran; 3) mencari solusi dari masalah, meliputi: mencari permasalahan yang sedang terjadi di pasaran, dan cara baru yang lebih baik; dan 4) berimajinasi, meliputi: variasi yang berbeda, dan dan menciptakan ide baru.

\section{Efikasi Diri}

Teori efikasi diri (self-efficiancy theory) dikenal sebagai teori kognitif sosial, atau teori pembelajaran sosial, mengacu pada keyakinan individu bahwa dia mampu untuk melaksanakan tugas. Semakin tinggi efikasi diri, maka akan semakin tinggi pula tingkat kepercayaan diri seseorang pada kemampuan untuk berhasil (Robbins dan Judge, 2015:139). Dengan demikian, dalam situasi yang sulit, orang dengan efikasi diri yang rendah lebih cenderung untuk mengurangi upaya mereka atau menyerahkan sekaligus, sementara itu orang dengan efikasi diri yang tinggi akan berusaha dengan lebih keras untuk menguasai tantangan.

Bandura sangat menekankan bahwa efikasi diri adalah mekanisme psikologis yang paling penting dari pengaruh diri (self-influencer). Dia menyatakan, "Jika orang tidak yakin bahwa mereka dapat menghasilkan efek yang diinginkan dan mencegah hal yang tidak diinginkan dengan tindakan merekan, maka mereka memiliki sedikit dorongan untuk bertindak. Faktor apa pun yang bertindak sebagai motivator, berakar dalam keyakinan utama untuk bahwa seseorang yang punya kekuasaan untuk membuahkan hasil yang diinginkan" (Luthan, 2006:275).

Menurut Schermerhorn, Jr. John R., James. G Hunt, Richard N. Osborn, and Mary UhlBien dalam Wibowo (2013: 162) ada empat cara untuk membangun atau meningkatkan efikasi diri, yaitu: Enactive mastery, , Vicarious modeling, Verbal persuation, Emotional arousal,

Menurut Bandura dalam Luthan (2006: 78) perbedaan self efficacy pada setiap individu terletak pada tiga komponen adalah Magnitude, Strength, dan Generality. Masingmasing mempunyai implikasi penting di dalam performansi yang secara lebih jelas dapat diuraikan sebagai berikut: Tingkat kesulitan tugas (Magnitude), Kekuatan keyakinan (Strength), Generalitas (Generality).

Efikasi diri merupakan rasa percaya diri yang dimiliki seseorang bahwa dirinya mampu untuk menyelesaikan tugas dengan efektif dan efisien sehingga tugas tersebut menghasilkan dampak yang diharapkan. Efikasi diri yang merujuk pada keyakinan diri sendiri mampu melakukan sesuatu yang diinginkannya, dapat dijadikan prediksi tingkah laku. Dengan indikator yaitu: 1) Tingkat kesulitan tugas (Magnitude); 2) Kekuatan keyakinan (Strength); dan 3) Generalitas (Generality).

\section{Motivasi Berwirausaha}

Menurut Alma (2018: 89) motivasi adalah kemauan untuk berbuat sesuatu, sedangkan motif adalah kebutuhan, keinginan, dorongan atau impuls. Motivasi seseorang tergantung kepada kekuatan motifnya. Motif dengan kekuatan yang sangat besarlah yang akan menentukan perilaku seseorang. Motif yang kuat ini seringkali berkurang apabila telah mencapai kepuasan ataupun karena menemui kegagalan. Jadi motif ini dapat berubah karena: a) terpuaskannya kebutuhan, artinya apabila kebutuhan telah terpuaskan maka motif akan berkurang, dan beralih kepada kebutuhan lain dan seterusnya. b) karena adanya hambatan, amak orang mencoba mengalihkan motifnya kea rah lain.

Menurut Saiman (2014: 26) mengemukan empat faktor yang memotivasi seseorang untuk berwirausaha, yaitu sebagai berikut: Laba , Kebebasan, Impian Personal, Kemandirian

Motivasi merupakan dorongan psikologis dari dalam maupun luar diri seseorang untuk bisa melakukan wirausaha. Dengan adanya dorongan tersebut, seseorang dapat menentukan usaha apa yang akan dikelolanya sekaligus juga dapat menentukan nasibnya dimasa depan. Dengan indikator yaitu: 1) Laba; 2) Kebebasan; 3) Impian personal; 4) Kemandirian; 5) 
Kebutuhan fisiologi/dasar (basic need); 6) Kebutuhan rasa aman (safety need); 7) Kebutuhan sosial (social need), dan 8) Kebutuhan pengakuan diri (self actualization).

\section{Kerangka Pemikiran}

Berdasarkan pemaparan teori, kajian dari penelitian terdahulu, dan pengaruh antar variabel di atas, maka untuk menjawab permasalahan penelitian dibentuk kerangka pemikiran seperti terlihat pada gambar berikut;

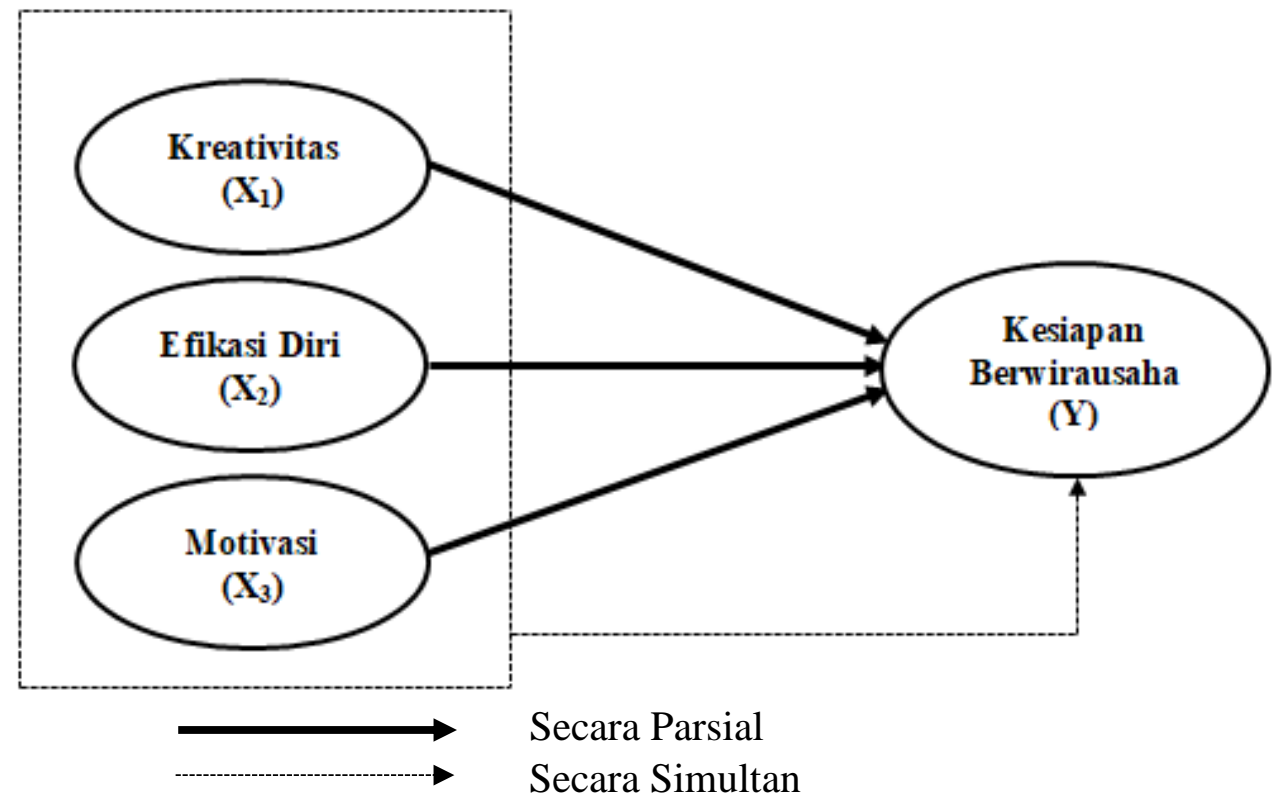

Gambar 1. Kerangka Berpikir

\section{Hipotesis}

Berdasarkan rumusan masalah dan beberapa asumsi yang telah dikemukakan terdahulu dapat dirumuskan hipotesis yang merupakan dugaan sementara. Penulis merumuskan hipotesis berkenaan dengan masalah yang diteliti sebagai berikut:

1. Ho: Tidak terdapat pengaruh kreativitas terhadap kesiapan berwirausaha

Ha: Terdapat pengaruh kreativitas terhadap kesiapan berwirausaha.

2. Ho: Tidak terdapat pengaruh efikasi diri terhadap kesiapan berwirausaha.

Ha: Terdapat pengaruh efikasi diri terhadap kesiapan berwirausaha.

3. Ho: Tidak terdapat pengaruh motivasi terhadap kesiapan berwirausaha.

Ha: Terdapat pengaruh motivasi terhadap kesiapan berwirausaha.

4. Ho: Tidak terdapat pengaruh kreativitas, efikasi diri dan motivasi secara bersama-sama terhadap kesiapan berwirausaha.

Ha: Terdapat pengaruh kreativitas, efikasi diri dan motivasi secara bersama-sama terhadap kesiapan berwirausaha.

\section{METODE PENELITIAN}

\section{Rancangan Penelitian}

Penelitian ini dilakukan melalui survey dengan menyebarkan angket kepada mahasiswa Fakultas Keguruan dan Ilmu Pendidikan Unversitas Jambi, dengan menggunakan pendekatan kuantitatif. Pendekatan kuantitatif yaitu suatu pendekatan untuk melihat pengaruh antara variabel penelitian dan menguji hipotesis yang telah dirumuskan sebelumnya. Walaupun 
uraiannya juga mengandung narasi atau bersifat deskriptif, sebagai penelitian pengaruh, fokusnya terletak pada penjelasan pada pengaruh antar variabel.

\section{Populasi dan Sampel}

Populasi adalah wilayah generalisasi yang terdiri dari atas objek/subjek yang mempunyai kualitas dan karakteristik tertentu yang ditetapkan oleh peneliti untuk dipelajari dan kemudian ditarik kesimpulannya (Sugiyono, 2012:83).

Adapun populasi dalam penelitian ini adalah mahasiswa Fakultas Keguruan dan Ilmu Pendidikan (FKIP) Universitas Jambi yang telah mengikuti mata kuliah kewirausahaan tahun tahun 2016 dan 2017 yang terdiri dari enam kelas dengan jumlah 236 mahasiswa. Dikarenakan penelitian ini membutuhkan sampel yang besar, maka teknik penarikan sampel dalam penelitian ini menggunakan teknik sampling jenuh (sampling sensus). Sampling jenuh menurut Sugiyono (2012:96) adalah teknik penentuan sampel apabila semua anggota populasi digunakan sebagai sampel. Istilah lain sampel jenuh adalah sensus, dimana semua anggota populasi dijadikan sampel.jumlah sampel dalam penelitian adalah 236 mahasiswa.

\section{Uji Prasyarat}

Uji Prasyarat untuk menentukan data tersebut bisa dipakai untuk tahap teknis analisis data yaitu menggunakan Uji Normalitas, Uji Linearlitas, Uji Homogenitas.

\section{Teknik Analisis Data}

Peneliti melakukan analisa terhadap data yang telah diuraikan dengan menggunakan metode kualitatif dan metode kuantitatif dengan menggunakan uji instrument penelitian, uji asumsi klasik, persamaan regresi linear berganda, koefisien determinasi, uji parsial dan uji simultan.

\section{HASIL DAN PEMBAHASAN}

\section{Hasil Analisis Statistik Deskriptif Variabel Penelitian}

Dalam penelitian ini analisis deskriptif dilakukan untuk menggambarkan kondisi mengenai kreativitas, efikasi diri, motivasi berwirausaha dan kesiapan berwirausaha mahasiswa/I Fakultas Keguruan dan Ilmu Pendidikan (FKIP) Universitas Jambi dengan menggunakan skala Likert.

a. Deskripsi Data Variabel Kesiapan Berwirausaha (Y)

Berdasarkan hasil sebaran angket yang dilakukan, diperoleh skor rata-rata variabel kesiapan berwirausaha sebesar 642,93, apabila dilihat pada kriteria presentase skor responden terhadap skor ideal Tabel 3.5 tampak bahwasanya variabel kesiapan berwirausaha mahasiswa/I termasuk pada range 535,6 - 700,3 berada pada kriteria Cukup Siap

b. Deskripsi Data Variabel Kreativitas $\left(\mathrm{X}_{1}\right)$

Berdasarkan hasil sebaran angket yang dilakukan, diperoleh skor rata-rata variabel kreativitas sebesar 702,8, apabila dilihat pada kriteria presentase skor responden terhadap skor ideal Tabel 3.5 tampak bahwasanya variabel kreativitas mahasiswa/I termasuk pada range 535,6 - 700,3 berada pada kriteria Tinggi.

c. Deskripsi Data Variabel Efikasi Diri $\left(\mathrm{X}_{2}\right)$

Berdasarkan hasil sebaran angket yang dilakukan, diperoleh skor rata-rata variabel efikasi diri sebesar 689,75 , apabila dilihat pada kriteria presentase skor responden terhadap skor ideal Tabel 3.5 tampak bahwasanya variabel efikasi diri mahasiswa/I termasuk pada range 535,6 - 700,3 berada pada kriteria Cukup Tinggi.

d. Deskripsi Data Variabel Motivasi Berwirausaha $\left(\mathrm{X}_{3}\right)$ 
Berdasarkan hasil sebaran angket yang dilakukan, diperoleh skor rata-rata variabel motivasi berwirausaha sebesar 688,95, apabila dilihat pada kriteria presentase skor responden terhadap skor ideal Tabel 3.5 tampak bahwasanya variabel efikasi diri mahasiswa/I termasuk pada range 535,6 - 700,3 berada pada kriteria Cukup Tinggi.

\section{Hasil Uji Prasyarat}

Persyaratan untuk menggunakan analisis regresi berganda adalah terpenuhinya asumsi klasik. Untuk mendapatkan nilai pemeriksa yang efisien dan tidak bias atau BLUE (Best Linear Unbias Estimator) dari satu persamaan regresi berganda dengan metode kuadrat terkecil (least square), maka perlu dilakukan pengujian untuk mengetahui model regresi yang dihasilkan memenuhi persyaratan asumsi klasik. Dalam penelitian ini akan di kemukakan uji asumsi klasik yang umum digunakan, yaitu Uji Normalitas, Uji Homogenitas dan Uji Linearitas sebagai berikut.

a. Uji Normalitas

Pada prinsipnya normalitas dapat ditandai dengan ujung garis kurva berada pada yang berimbang di sisi kiri dan dengan garis sisi kanan histrogram. Ujung kedua sisi garis kurva berada pada titik kedua sudut masing-masing yang sama di kiri dan kanan disebut normal. Bila titik kurvanya salah satu atau kedua tidak berada tepat di sudut, maka disebut tidak normal (Kahirinal, 2016:400). Dikarenakan ujung kedua sisi garis kurva pada gambar histogram di atas berada pada titik kedua sudut masing-masing yang sama di kiri dan kanan, maka dengan dapat disimpulkan bahwa data dalam penelitian ini berdistribusi normal.

b. Uji Homogenitas

Dari hasil Test of Homogeneity of Variances, diperoleh nilai Sig untuk ketiga variable independent $>0,05$ (syarat homogenitas), artinya ketiga variable penelitian bersifat homogen.

c. Uji Linearitas (Model)

Linier yaitu apabila titik-titik dalam model menyebar tidak terpola berada mendekati tidak jauh di atas atau dibawah garis diagonal (Khairinal, 2016:401). Dikarenakan titiktitik dalam model menyebar tidak terpola berada mendekati tidak jauh di atas atau dibawah garis diagonal, maka dengan demikian dapat disimpulkan data dalam penelitian ini bermakna linier.

\section{Hasil Uji Asumsi Regresi}

a. Uji Multikolinearitas

Dari hasil uji multikolinieritas menunjukan bahwa semua variable penelitian memiliki nilai VIF (variance inflation factor) di atas lebih kecil dari 5, dimana nilai terendah 1,740 dan tertinggi 3,403 lebih kecil dari $5(<5)$ batas nilai toleransi yang ditentukan dalam penelitian ini, artinya bilai nilai VIF lebih kecil 5 dari batas nilai toleransi yang ditentukan adalah tidak terjadi multikolinieritas atau tidak terjadi hubungan antara setiap variable yang ada dalam model penelitian.

b. Uji Heterokedastisitas

Dari hasil uji heterokedastisitas melalui scatterplots terlihat bahwa titik-titik menyebar secara acak serta tersebar baik diatas maupun dibawah angka 0 pada sumbu Y. Hal ini dapat disimpulkan bahwa tidak terjadi heterokedastisitas pada model, sehingga model layak dipakai untuk memprediksi penggunaan jasa akomodasi berdasarkan masukan variabel independent.

c. Uji Autokorelasi

Dari hasil uji autokorelasi yang dilakukan diperoleh nilai Durbin Watson sebesar 2,104, pembanding menggunakan nilai signifikansi 5\%, jumlah sampel 206 (n), dan jumlah 
variabel independen $3(\mathrm{k}=3)$, maka di tabel DurbinWatson akan didapat nilai du sebesar 1,799. Karena nilai DW 2,104 lebih besar dari batas atas (du) 1,799 dan kurang dari 4 1,799 (2,201), maka dapat disimpulkan hipotesis nol diterima, yang berarti tidak ada korelasi.

\section{Hasil Persamaan Regresi Linear Berganda}

Berdasarkan estimasi regresi berganda dengan program SPSS 21.0 diperoleh hasil seperti Tabel 1 berikut.

Tabel 1. Tabel Coefficients

Coefficients $^{\mathbf{a}}$

\begin{tabular}{|l|r|r|r|r|r|}
\hline \multirow{2}{*}{ Model } & \multicolumn{2}{|c|}{$\begin{array}{c}\text { Unstandardized } \\
\text { Coefficients }\end{array}$} & $\begin{array}{c}\text { Standardized } \\
\text { Coefficients }\end{array}$ & \multirow{2}{*}{$\mathrm{t}$} & \multirow{2}{*}{ Sig. } \\
\cline { 2 - 4 } & \multicolumn{1}{|c|}{$\mathrm{B}$} & Std. Error & \multicolumn{1}{c|}{ Beta } & & \\
\hline \multirow{2}{*}{ (Constant) } &, 053 &, 189 & &, 280 &, 779 \\
\multirow{2}{*}{1} &, 247 &, 072 &, 232 & 3,444 &, 001 \\
X1_Kreativitas &, 157 &, 058 &, 132 & 2,699 &, 008 \\
X2_EfikasiD &, 596 &, 073 &, 556 & 8,156 &, 000 \\
\hline
\end{tabular}

a. Dependent Variable: Y_KesiapanBer

Secara statistik diperoleh persamaan regresi sebagai berikut.

$\mathrm{Y}=\mathrm{a}+\mathrm{b}_{1} \mathrm{X}_{1}+\mathrm{b}_{2} \mathrm{X}_{2}+\mathrm{b}_{3} \mathrm{X}_{3}+\mathrm{e}$

$Y=0,053+0,247 \cdot X_{1}+0,157 \cdot X_{2}+0,596 \cdot X_{3}+e$

Dari persamaan regresi linear berganda di atas dapat disimpulkan sebagai berikut:

* Nilai Konstanta = 0,053

Nilai konstanta positif menunjukan pengaruh positif variabel independent (kreativitas, efikasi diri dan motivasi berwirausaha), artinya apabila variabel independent bersifat konstans atau tidak dilaksanakan dengan baik maka nilai kesiapan berwirausaha mahasiswa yaitu sebesar 0,053 skala/satuan.

* Kreativitas $\left(\mathrm{X}_{1}\right)=0,247$

Merupakan koefisien regresi variabel kreativitas $\left(\mathrm{X}_{1}\right)$ terhadap variabel kesiapan berwirauwaha (Y). Yang memiliki makna bahwa setiap penambahan satu nilai kreativitas yang dimiliki mahasiswa akan menaikan nilai kesiapan berwirausaha mahasiswa yaitu sebesar 0,247, atau dengan kata lain apabila kreatitivitas mahasiswa dapat ditingkatkan kualitasnya sebesar 100 skala, maka hal itu akan diikuti pula dengan peningkatan kesiapan berwirausaha mahasiswa sebesar 100 skala.

* Efikasi Diri $\left(\mathrm{X}_{2}\right)=0,157$

Merupakan koefisien regresi variabel efikasi diri $\left(\mathrm{X}_{2}\right)$ terhadap variabel kesiapan berwirausaha mahasiswa (Y). Yang memiliki makna bahwa setiap penambahan satu nilai efikasi diri akan menaikan nilai kesiapan berwirausaha mahasiswa sebesar 0,157, atau dengan kata lain apabila efikasi diri yang dimiliki oleh mahasiwa ditingkatkan kualitasnya sebesar 100 skala, maka hal itu akan diikuti pula dengan peningkatan kesiapan berwirausaha mahasiswa sebesar 100 skala.

* Motivasi Berwirausaha $\left(\mathrm{X}_{3}\right)=0,596$

Merupakan koefisien regresi variabel motivasi berwirausaha $\left(\mathrm{X}_{3}\right)$ terhadap variabel kesiapan berwirausaha mahasiswa (Y). Yang memiliki makna bahwa setiap penambahan satu nilai motivasi berwirausaha akan meningkatkan nilai kesiapan berwirausaha mahasiswa sebesar 0,596, atau dengan kata lain apabila motivasi 
berwirausaha dapat ditingkatkan sebesar 100 skala, maka hal itu akan diikuti pula dengan peningkatan kesiapan berwirausaha mahasiswa sebesar 100 skala.

\section{Pengujian Hipotesis \\ Pengujian Hipotesis Pertama}

Hipotesis pertama yang diajukan dalam penelitian ini adalah kreativitas berwirausaha berpengaruh signifikan terhadap kesiapan berwirausaha mahasiswa Fakultas Keguruan dan Ilmu Pendidikan Universitas Jambi. Untuk mengetahui ada tidaknya pengaruh kreativitas terhadap kesiapan berwirausaha, maka dilakukan pengujian hipotesis sebagai berikut:

Tabel 2. Output Persamaan Regresi Kreativitas Terhadap Kesiapan Berwirausaha

\begin{tabular}{|c|c|c|c|c|c|c|}
\hline \multicolumn{7}{|c|}{ Coefficients $^{a}$} \\
\hline \multirow{2}{*}{\multicolumn{2}{|c|}{ Model }} & \multicolumn{2}{|c|}{$\begin{array}{c}\text { Unstandardized } \\
\text { Coefficients }\end{array}$} & \multirow{2}{*}{$\begin{array}{c}\begin{array}{c}\text { Standardized } \\
\text { Coefficients }\end{array} \\
\text { Beta }\end{array}$} & \multirow[t]{2}{*}{$\mathrm{t}$} & \multirow[t]{2}{*}{ Sig. } \\
\hline & & $\mathrm{B}$ & Std. Error & & & \\
\hline \multirow{2}{*}{1} & (Constant) & 693 & 189 & & 3,660 & ,000 \\
\hline & X1_Kreativitas & & & ,773 & &, 000 \\
\hline
\end{tabular}

a. Dependent Variable: $Y \_K e s i a p a n B e r$

Dari hasil uji regresi pada Tabel 4.10 di atas dengan menggunakan SPSS 21.0 diperoleh angka $t$ hitung variabel kreativitas sebesar 17,389, dikarenakan nilai $t_{\text {hitung }} 17,389>1,972$ sehingga Ho ditolak dan $\mathrm{H}_{\mathrm{a}}$ diterima yang artinya ada pengaruh kreativitas terhadap kesiapan berwirausaha. Sedangkan untuk melihat nilai signifikannya, diperoleh nilai signifikan sebesar 0,00 , dikarenakan angka taraf signifikansi $<0,05(0,000<0,05)$ maka dapat disimpulkan kreativitas berpengaruh terhadap kesiapan berwirausaha mahasiswa. Dimana besarnya pengaruh kreativitas terhadap kesiapan berwirausaha mahasiswa dapat dilihat pada Tabel 3 berikut.

Tabel 3. Koefisien Determinasi Kreativitas Terhadap Kesiapan Berwirausaha.

\begin{tabular}{|l|r|r|r|c|}
\hline Model & $R$ & $R$ Square & $\begin{array}{c}\text { Adjusted R } \\
\text { Square }\end{array}$ & $\begin{array}{c}\text { Std. Error of the } \\
\text { Estimate }\end{array}$ \\
\hline 1 &, $773^{\mathrm{a}}$ &, 597 &, 595 &, 341278131 \\
\hline
\end{tabular}

a. Predictors: (Constant), X1_Kreativitas

Dari table model summary di atas diperoleh nilai R Square sebesar 0,597. Nilai ini menunjukan besarnya pengaruh kreativitas terhadap kesiapan berwirausaha yaitu sebesar 59,7 persen. Sedangkan sisanya sebesar 40,3 persen dipengaruhi oleh factor lain yang tidak termasuk dalam model ini.

\section{Pengujian Hipotesis Kedua}

Hipotesis kedua yang diajukan dalam penelitian ini adalah efikasi diri berpengaruh signifikan terhadap kesiapan berwirausaha mahasiswa Fakultas Keguruan dan Ilmu Pendidikan Universitas Jambi. Untuk mengetahui ada tidaknya pengaruh efikasi diri terhadap kesiapan berwirausaha, maka dilakukan pengujian hipotesis sebagai berikut: 
Tabel 4. Output Persamaan Regresi Efikasi Diri Terhadap Kesiapan Berwirausaha

\begin{tabular}{|c|c|c|c|c|c|c|}
\hline \multicolumn{7}{|c|}{ Coefficients $^{a}$} \\
\hline \multirow{2}{*}{\multicolumn{2}{|c|}{ Model }} & \multicolumn{2}{|c|}{ Unstandardized Coefficients } & \multirow{2}{*}{$\begin{array}{c}\text { Standardized } \\
\text { Coefficients } \\
\text { Beta }\end{array}$} & \multirow[t]{2}{*}{$\mathrm{t}$} & \multirow[t]{2}{*}{ Sig. } \\
\hline & & B & Std. Error & & & \\
\hline \multirow{2}{*}{1} & (Constant) & ,988 & 262 & & 3,775 &, 000 \\
\hline & & & & ,625 & &, 000 \\
\hline
\end{tabular}

a. Dependent Variable: Y_KesiapanBer

Dari hasil uji regresi pada Tabel 4 di atas dengan menggunakan SPSS 21.0 diperoleh angka $t$ hitung variabel efikasi diri sebesar 11,428, dikarenakan nilai thitung 11,428 > 1,972 sehingga $\mathrm{Ho}$ ditolak dan $\mathrm{H}_{\mathrm{a}}$ diterima yang artinya ada pengaruh efikasi diri terhadap kesiapan berwirausaha. Sedangkan untuk melihat nilai signifikannya, diperoleh nilai signifikan sebesar 0,00, dikarenakan angka taraf signifikansi $<0,05(0,000<0,05)$ maka dapat disimpulkan efikasi diri berpengaruh terhadap kesiapan berwirausaha mahasiswa. Dimana besarnya pengaruh efikasi diri terhadap kesiapan berwirausaha mahasiswa dapat dilihat pada Tabel 5 berikut.

Tabel 5. Koefisien Determinasi Efikasi Diri Terhadap Kesiapan Berwirausaha.

\begin{tabular}{|l|r|r|r|c|}
\hline Model & $\mathrm{R}$ & $\mathrm{R}$ Square & $\begin{array}{c}\text { Adjusted R } \\
\text { Square }\end{array}$ & $\begin{array}{c}\text { Std. Error of the } \\
\text { Estimate }\end{array}$ \\
\hline 1 &, $625^{\mathrm{a}}$ &, 390 &, 387 &, 4198479969 \\
\hline
\end{tabular}

a. Predictors: (Constant), X2_EfikasiD

Dari table model summary di atas diperoleh nilai $\mathrm{R}$ Square sebesar 0,390. Nilai ini menunjukan besarnya pengaruh efikasi diri terhadap kesiapan berwirausaha yaitu sebesar 39 persen. Sedangkan sisanya sebesar 61 persen dipengaruhi oleh factor lain yang tidak termasuk dalam model ini.

\section{Pengujian Hipotesis Ketiga}

Hipotesis ketiga yang diajukan dalam penelitian ini adalah motivasi berwirausaha berpengaruh signifikan terhadap kesiapan berwirausaha mahasiswa Fakultas Keguruan dan Ilmu Pendidikan Universitas Jambi. Untuk mengetahui ada tidaknya pengaruh motivasi berwirausaha terhadap kesiapan berwirausaha, maka dilakukan pengujian hipotesis sebagai berikut:

Tabel 6. Output Persamaan Regresi Motivasi Berwirausaha Terhadap Kesiapan Berwirausaha

\begin{tabular}{|c|c|c|c|c|c|}
\hline \multicolumn{6}{|c|}{ Coefficients $^{a}$} \\
\hline \multirow[t]{2}{*}{ Model } & \multicolumn{2}{|c|}{ Unstandardized Coefficients } & Standardized & $\mathrm{t}$ & Sig. \\
\hline & $\mathrm{B}$ & Std. Error & Beta & & \\
\hline $1 \quad$ (Constant) & 367 & , 170 & & 2,157 &, 032 \\
\hline
\end{tabular}




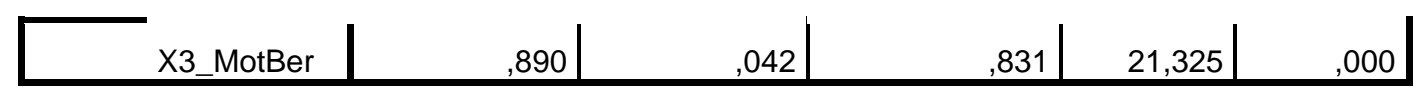

a. Dependent Variable: Y_KesiapanBer

Dari hasil uji regresi pada Tabel 6 di atas dengan menggunakan SPSS 21.0 diperoleh angka t hitung variabel motivasi berwirausaha sebesar 21,325, dikarenakan nilai thitung 21,325 $>$ 1,972 sehingga $\mathrm{H}_{o}$ ditolak dan $\mathrm{H}_{\mathrm{a}}$ diterima yang artinya ada pengaruh motivasi berwirausaha terhadap kesiapan berwirausaha. Sedangkan untuk melihat nilai signifikannya, diperoleh nilai signifikan sebesar 0,00, dikarenakan angka taraf signifikansi $<0,05(0,000<$ 0,05) maka dapat disimpulkan motivasi berwirausaha berpengaruh terhadap kesiapan berwirausaha mahasiswa. Dimana besarnya pengaruh motivasi berwirausaha terhadap kesiapan berwirausaha mahasiswa dapat dilihat pada Tabel 7 berikut.

Tabel 7. Koefisien Determinasi Motivasi berwirausaha Terhadap Kesiapan Berwirausaha.

\begin{tabular}{|l|r|r|r|c|}
\hline Model & $R$ & $R$ Square & $\begin{array}{c}\text { Adjusted R } \\
\text { Square }\end{array}$ & $\begin{array}{c}\text { Std. Error of the } \\
\text { Estimate }\end{array}$ \\
\hline 1 &, $831^{\mathrm{a}}$ &, 690 &, 689 &, 29921633897 \\
\hline
\end{tabular}

a. Predictors: (Constant), X3_MotBer

Dari table model summary di atas diperoleh nilai $\mathrm{R}$ Square sebesar 0,690. Nilai ini menunjukan besarnya pengaruh motivasi berwirausaha terhadap kesiapan berwirausaha yaitu sebesar 69 persen. Sedangkan sisanya sebesar 31 persen dipengaruhi oleh factor lain yang tidak termasuk dalam model ini.

\section{Pengujian Hipotesis Keempat}

Hipotesis keempat yang diajukan dalam penelitian ini adalah kreativitas, efikasi diri, dan motivasi berwirausaha secara bersama-sama berpengaruh signifikan terhadap kesiapan berwirausaha mahasiswa Fakultas Keguruan dan Ilmu Pendidikan Universitas Jambi. Untuk mengetahui ada tidaknya pengaruh secara simultan atau secara bersama-sama, maka dilakukan pengujian hipotesis sebagai berikut:

Tabel 8. Hasil Uji F Secara Simultan

ANOVA $^{\mathrm{a}}$

\begin{tabular}{|rl|r|r|r|c|c|}
\hline \multicolumn{1}{|l|}{ Model } & \multicolumn{1}{c|}{$\begin{array}{c}\text { Sum of } \\
\text { Squares }\end{array}$} & Df & Mean Square & F & Sig. \\
\hline \multirow{2}{*}{1} & Regression & 42,684 & 3 & 14,228 & 176,371 &, $000^{\mathrm{b}}$ \\
& Residual & 16,295 & 202 &, 081 & & \\
& Total & 58,979 & 205 & & & \\
\hline
\end{tabular}

a. Dependent Variable: Y_KesiapanBer

b. Predictors: (Constant), X3_MotBer, X2_EfikasiD, X1_Kreativitas

Dari uji Anova atau $F$ test dengan menggunakan SPSS 21.0 didapat $F_{\text {hitung }}$ sebesar 176,371, dikarenakan nilai $F_{\text {hitung }} 176,371>2,65$ sehingga Ho ditolak dan $\mathrm{H}_{\mathrm{a}}$ diterima yang artinya ada pengaruh kreativitas, efikasi diri dan motivasi berwirausaha secara bersama-sama (simultan) terhadap kesiapan berwirausaha. Sedangkan untuk melihat nilai signifikannya, diperoleh nilai signifikan sebesar 0,00, dikarenakan angka taraf signifikansi jauh lebih $<0,05$ $(0,000<0,05)$ maka dapat disimpulkan bahwa kreativitas, efikasi diri dan motivasi 
berwirausaha secara bersama-sama (simultan) berpengaruh secara signifikan terhadap kesiapan berwirausaha mahasiswa FKIP Universitas Jambi.

Tabel 9. Uji R dan dan R Square

\begin{tabular}{|c|c|c|c|c|}
\hline \multicolumn{5}{|c|}{ Model Summary } \\
\hline Model & $\mathrm{R}$ & R Square & $\begin{array}{l}\text { Adjusted R } \\
\text { Square }\end{array}$ & $\begin{array}{l}\text { Std. Error of } \\
\text { the Estimate }\end{array}$ \\
\hline 1 & $851^{\mathrm{a}}$ & ,724 & ,720 & 28402 \\
\hline
\end{tabular}

a. Predictors: (Constant), X3_MotBer, X2_EfikasiD,

X1_Kreativitas

Nilai R sebesar 0,851 menunjukan korelasi ganda (kreativitas, efikasi diri dan motivasi berwirausaha) dengan kesiapan berwirausaha mahasiswa. Dengan mempertimbangkan variasi Nilai R Square sebesar 0,724, artinya persentase sumbangan pengaruh variabel kreativitas, efikasi diri dan motivasi berwirausaha terhadap kesiapan berwirausaha mahasiswa yaitu sebesar $72,4 \%$, sedangkan sisanya sebesar $27,6 \%$ dipengaruhi oleh variabel lain yang tidak dimasukan dalam model ini.

\section{Pembahasan}

\section{Deskripsi Variabel Penelitian.}

a. Kesiapan Berwirausaha

Dari hasil survey yang dilakukan diketahui bahwa mahasiswa/i pada FKIP Universitas Jambi masih cukup siap untuk berwirausaha setelah mereka lulus dari perguruan tinggi nanti, artinya mereka belum benar-benar siap untuk menjadi seorang entreprenuership setelah mereka menyelesaikan studi pada perguruan tinggi.

b. Kreativitas

Dari hasil survey yang dilakukan diketahui bahwa mahasiswa/i pada FKIP Universitas Jambi memiliki kreativitas yang tinggi.

c. Efikasi Diri

Dari hasil survey yang dilakukan diketahui bahwa mahasiswa/i pada FKIP Universitas Jambi memiliki kepercayaan diri yang cukup tinggi untuk berwirausaha.

d. Motivasi Berwirausaha

Dari hasil survey yang dilakukan diketahui bahwa mahasiswa/i pada FKIP Universitas Jambi memiliki motivasi berwirausaha yang cukup tinggi.

\section{Pengaruh Kreativitas Terhadap Kesiapan Berwirausaha}

Dari pengujian hipotesis yang dilakukan diketahui bahwa kreativitas berpengaruh positif signifikan terhadap kesiapan berwirausaha. Hasil penelitian ini sejalan dengan hasil penelitian yang dilakukan oleh Wijayanti, L.N.E.R., Sutikno, T.A., dan Sukarnati (2016:1365) yang mengemukakan bahwa seorang yang memiliki kreativitas yang tinggi cenderung lebih siap baginya untuk berwirausaha dibandingkan dengan orang yang tidaka memiliki ide kreatif. Hal ini dikarenakan seseorang yang kreatif akan lebih mudah mengembangkan ide, serta menggunakan sumber daya untuk mencari peluang dalam melakukan perbaikan hidup.

\section{Pengaruh Efikasi Diri Terhadap Kesiapan Berwirausaha}

Dari pengujian hipotesis yang dilakukan, diketahui bahwa efikasi diri berpengaruh terhadap kesiapan berwirausaha. Hasil penelitian ini sejalan dengan hasil penelitian yang 
dilakukan oleh Sari, A.K (2013:1) yang mengemukakan bahwa efikasi diri memberikan pengaruh yang besar pada diri seseorang terhadap kesiapan berwirausaha. hal ini dikarenakan bahwa efikasi diri mempengaruhi bentuk tindakan yang akan mereka pilih untuk dilakukan, sebanyak apa usaha yang akan mereka berikan ke dalam aktivitas ini, selama apa mereka akan bertahan menghadapi rintangan dan kegagalan, serta ketangguhan mereka mengikuti adanya kemunduran". Keyakinan dan kemampuan diri mahasiswa inilah yang berkaitan dengan motivasinya. Selain itu Luthans (2006) juga mengemukakan keyakinan diri sebagai kepercayaan tentang kemampuanya untuk menggerakan motivasi, sumber daya kognitif, dan cara bertindak yang diperlukan untuk berhasil melaksanakan tugas konteks tertentu.

\section{Pengaruh Motivasi Berwirausaha Terhadap Kesiapan Berwirausaha}

Dari pengujian hipotesis yang dilakukan, diketahui bahwa motivasi berwirausaha berpengaruh terhadap kesiapan berwirausaha. Hasil penelitian ini sejalan dengan hasil penelitian yang dilakukan oleh Nastiti, N.D (2019:61) yang mengungkapkan bahwa motivasi kewirausahaan merupakan faktor yang paling mempengaruhi mahasiswa terhadap kesiapan berwirausaha. Lebih lanjut Nastiti, N.D (2019:61) mengungkapkan bahwa motivasi sebagai dasar pendorong untuk melakukan kegiatan wirausaha memegang peranan yang penting. Individu yang memiliki banyak pengetahuan mengenai kewirausahaan, tidak akan terjun ke dunia wirausaha jika tidak memiliki motivasi untuk menjadi seorang wirausaha.

\section{Pengaruh Kreativitas, Efikasi Diri dan Motivasi Berwirausaha Secara Simultan Terhadap Kesiapan Berwirausaha.}

Dari hasil pengujian yang dilakukan secara secara simultan dengan menggunakan uji $\mathrm{F}$ diketahui bahwa kreativitas, efikasi diri dan motivasi berwirausaha pengaruh terhadap kesiapan berwirausaha mahasiswa. Hal ini menunjukan jika mahasiswa FKIP Universitas Jambi mampu mengimplementasikan kreativitas, efikasi diri dan motivasi berwirausaha secara bersama-sama, maka akan mampu meningkatkan kesiapan mahasiswa untuk berwirausaha baik itu dari Kemampuan Mental; Berorientasi kemasa depan: pandangan dan keinginan yang kuat; Kemampuan mengambil resiko: mempelajari cara mengenal risiko dan mengatasi risiko; serta Keterampilan berwirausaha: membangun jaringan dan kemampuan mempengaruhi orang lain.

Kesiapan adalah tingkat perkembangan dari kematangan atau kedewasaan yang menguntungkan untuk dipraktikkan sesuatu. Pengertian ini mengacu pada pengetahuan, keterampilan serta sikap yang dimiliki seseorang berkaitan dengan tujuan yang akan dicapai. Kesiapan atau readiness merupakan kesediaan untuk memberikan respon atau bereaksi. Kesediaan itu datang dari dalam diri siswa dan juga berhubungan dengan kematangan. Kesiapan sangat perlu diperhatikan dalam suatu proses, karena jika siswa sudah ada kesiapan, maka hasilnya akan memuaskan (Chaplin, 2010:418).

\section{KESIMPULAN DAN SARAN}

\section{Kesimpulan}

Berdasarkan hasil penelitian yang diperoleh secara keseluruhan, maka dapat disimpulkan sebagai berikut:

1. Kreativitas, efikasi diri, motivasi berwirausaha dan kesiapan berwirausaha mahasiswa Fakultas Keguruan dan Ilmu Pendidikan Universitas Jambi dalam kondisi yang cukup tinggi.

2. Kreativitas memiliki pengaruh yang positif dan signifikan terhadap kesiapan berwirausaha mahasiswa Fakultas Keguruan dan Ilmu Pendidikan Universitas Jambi.

3. Efikasi diri memiliki pengaruh yang positif dan signifikan terhadap kesiapan berwirausaha mahasiswa Fakultas Keguruan dan Ilmu Pendidikan Universitas Jambi. 
4. Motivasi berwirausaha memiliki pengaruh yang positif dan signifikan terhadap kesiapan berwirausaha mahasiswa Fakultas Keguruan dan Ilmu Pendidikan Universitas Jambi.

5. Kreativitas, efikasi diri dan motivasi berwirausaha secara bersama-sama memiliki pengaruh yang positif dan signifikan terhadap kesiapan berwirausaha mahasiswa Fakultas Keguruan dan Ilmu Pendidikan Universitas Jambi

\section{Saran-saran}

\section{Secara Praktis}

Berdasarkan beberapa kesimpulan yang diperoleh, maka saran untuk dimasa mendatang sebagai berikut:

a. Diharapkan kedepan mahasiswa harus bisa memanfaatkan waktu sebaik baik mungkin ketika mereka masih duduk bangku perguruan tinggi untuk mengembangkan potensi diri dengan arahan, bimbingan dan saran dosen membuat agar lebih giat belajar dan berlatih kewirausahaan dengan memanfaatkan fasilitas kewirausahaan yang ada selama dibangku kuliah. Karena dengan begitu diharapkan dapat menumbuhkan kesiapan mereka yang lebih baik lagi untuk menjadi seorang entreprenuership.

b. Diharapkan kedepan dosen pada FKIP Universitas Jambi mampu memberikan dorongan kepada mahasiswa/inya untuk menuangkan ide-ide atau gagasan yang mereka miliki untuk dijadikan sebuah karya nyata, dan itu semua harus di mulai dari bangku kuliah, agar mahasiswa/i nantinya menjadi terbiasa hingga mereka menyelesaikan pendidikan dari peguruan tinggi dan mampu menjadi seorang wirausaha yang mandiri tanpa harus mencari pekerjaan lagi.

c. Diharapkan kedepan dosen pada FKIP Universitas Jambi mampu memberikan dorongan kepada mahasiswa/Inya dalam upaya meningkatkan keyakinan diri dan rasa percaya diri mahasiswanya untuk berwirausaha. Karena untuk menjadi seorang entrepreneurship yang sukses efikasi diri yang tinggi sangat dibutuhkan sekali, dengan memiliki efikasi diri yang tinggi seseorang akan mampu mengatasi setiap permasalahan yang ada, akan selalu bersemangat dalam menghadapi tantangan dalam usaha, serta akan terus berinovasi agar usaha yang dijalankan dapat berkembang pesat.

d. Diharapkan kedepan dosen maupun pihak kampus mampu menanamkan sikap optimis pada mahasiswa/i agar mau dan mampu untuk berwirausaha. Salah satunya yaitu dengan menceritakan kisah-kisah inspiratif orang-orang yang sukses melalui berwirausaha dari usia muda. Selain itu dosen juga dapat mendorong mahasiswanya untun dapat mengikuti pelatihan kewirausahaan atau seminar, agar dapat dijadikan bekal ketika sudah lulus sekolah. Hal ini dapat dijadikan alternatif apabila impiannya bekerja pada sektor formal tidak tercapai.

\section{Secara Akademis:}

Kesiapan berwirausaha mahasiswa/I Fakultas Keguruan dan Ilmu Pendidikan (FKIP) Universitas Jambi dapat dipengaruhi oleh faktor lain, oleh karena itu perlu kajian yang lebih komfrehensif, guna menjawab faktor lain (epsilon) yang mempengaruhi kesiapan berwirausaha mahasiswa selain dari kreativitas, efikasi diri dan motivasi berwirausaha.

\section{DAFTAR RUJUKAN}

Alma, B. (2018). Kewirausahaan. Bandung: Alpabeta.

Chaplin, J. P. (2010). Kamus Lengkap Psikologi. Jakarta: Rajagrafindo Persada.

Dalyono, M. (2011). Psikologi Pendidikan. Jakarta: Rineka Cipta.

Khairinal. (2016). Menyusun: Proposal, Skripsi, Tesis \& Disertasi. Jambi: Salim Media Indonesia.

Luthans, Fred. (2006). Perilaku Organisasi. Yogyakarta: Andi. 
Nastiti, N.D. (2019). Pengaruh Motivasi dan Pengetahuan Kewirausahaan Terhadap Kesiapan Berwirausaha Mahasiswa Program Studi Administrasi Bisnis Fakultas Ilmu Sosial dan Ilmu Politik Universitas Mulawarman. eJournal Administrasi Bisnis, Vol. 7, No. 1.

Puspitaningsih, F. (2014). Pengaruh Efikasi Diri dan Pengetahuan Kewirausahaan Terhadap Minat Berwirausaha Melalui Motivasi. Jurnal Ekonomi

Robbins, S.P. \& Judge, T. (2015). Organizational Behavior. Pearson: Education Limited.

Sari, A.K. (2013). Pengaruh Peran Orang Tua, Guru, dan Self-Efficacy Terhadap Kesiapan Berwirausaha Siswa SMK Muhammadiyah 1 Bantul Kompetensi Keahlian Audio Video Kelas XII.

Sari, I.P., \& Maya, S. (2017). Social Media dan Social Shooper Terhadap Motivasi Wirausaha pada Mahasiswa. Diskusi Panel Nasional Pendidikan Kewirausahaan LPPM Universitas Indraprasta PGRI Jakarta. Prosiding 2017 "Memajukan Kewirausahaan dalam Upaya Membangun Indonesia.

Saiman, L. (2014). Kewirausahaan, Teori, Praktik, dan Kasus-kasus. Jakarta: Salemba Empat.

Sugiyono. (2012). Statistika Untuk Penelitian. Bandung: Alfabeta.

Slameto. (2015). Belajar dan Faktor-Faktor Yang Mempengaruhi. Jakarta: Rineka Cipta.

Soemanto, W. (2013). Pendidikan Wiraswasta. Jakarta: Bumi Aksara.

Wibowo. (2013). Perilaku Dalam Organisasi. Jakarta: Raja Grafindo Persada.

Wijayanti, L.N.E.R., Sutikno, T.A., dan Sukarnati. (2016). Kontribusi Pengetahuan Kewirausahaan, Pengalaman Prakerin dan Kreativitas Terhadap Kesiapan Berwirausaha. Jurnal Pendidikan: Teori, Penelitian, dan Pengembangan. Volume 1, Nomor 7. 